\title{
Key conservation issues for migratory land- and waterbird species on the world's major flyways
}

\author{
JEFF S. KIRBY, ALISON J. STATTERSFIELD, STUART H. M. BUTCHART, \\ MICHAEL I. EVANS, RICHARD F. A. GRIMMETT, VICTORIA R. JONES, JOHN \\ O'SULLIVAN, GRAHAM M. TUCKER and IAN NEWTON
}

\section{Summary}

An estimated $19 \%$ of the world's 9,856 extant bird species are migratory, including some 1,600 species of land- and waterbirds. In $2008,11 \%$ of migratory land- and waterbirds were classed by BirdLife International as threatened or near-threatened on the IUCN Red List. Red List indices show that these migrants have become more threatened since 1988, with 33 species deteriorating and just six improving in status. There is also increasing evidence of regional declines. Population trend data show that more Nearctic-Neotropical migrants have declined than increased in North America since the 1980s, and more Palearctic-Afrotropical migrants breeding in Europe declined than increased during 1970-2000. Reviews of the status of migratory raptors show unfavourable conservation status for $51 \%$ of species in the African-Eurasian region (in 2005), and $33 \%$ of species in Central, South and East Asia (in 2007). Land-use change owing to agriculture is the most frequently cited threat affecting nearly $80 \%$ of all threatened and nearthreatened species. However, while agricultural intensification on the breeding grounds is often proposed as the major driver of declines in Palearctic-Afrotropical migrants, some species appear to be limited by the quantity and quality of available habitat in non-breeding areas, notably the drylands of tropical Africa. Forest fragmentation in breeding areas has contributed to the declines of Nearctic-Neotropical migrants with deforestation in non-breeding areas another possible factor. Infrastructure development including wind turbines, cables, towers and masts can also be a threat. Over-harvesting and persecution remain serious threats, particularly at key migration locations. Climate change is affecting birds already, is expected to exacerbate all these pressures, and may also increase competition between migratory and non-migratory species. The conservation of migratory birds thus requires a multitude of approaches. Many migratory birds require effective management of their critical sites, and Important Bird Areas (IBAs) provide an important foundation for such action; however to function effectively in conserving migratory species, IBAs need to be protected and the coherence of the network requires regular review. Since many migratory species (c. 55\%) are widely dispersed across their breeding or nonbreeding ranges, it is essential to address the human-induced changes at the wider landscape scale, a very considerable challenge. Efforts to conserve migratory birds in one part of the range are less effective if unaddressed threats are reducing these species' populations and habitats elsewhere. International collaboration and coordinated action along migration flyways as a whole are thus key elements in any strategy for the conservation of migratory birds.

\section{Introduction}

Migration has always fascinated humankind, and the arrival and departure of migrants is an intriguing phenomenon. Migratory birds link people, cultures, and development and conservation issues. They offer an extraordinary opportunity for international collaboration, 
and were one of the initial drivers for international conservation legislation, e.g. the 1916 North American Migratory Birds Treaty between USA and UK (on behalf of Canada). Despite this, and the commitment by governments to achieve by 2010 a significant reduction in the current rate of biodiversity loss, many migratory bird species are declining, undoubtedly in response to major environmental pressures. An overview of the status of migratory birds and the threats they face, and an introduction to the conservation approaches that must be taken to ensure their survival, is therefore our aim in this paper.

An estimated 1,855 (19\%) of the world's 9,856 extant bird species (BirdLife International $2008 \mathrm{a}, \mathrm{b}$ ) are migratory, defined here as species where a substantial proportion of the global or a regional population makes regular cyclical movements beyond the breeding range, with predictable timing and destinations (see more detailed definitions in Supplementary materials). The Convention on Migratory Species (CMS) uses a similar definition, but specifies that, to qualify as migratory under the Convention, a significant proportion of the population of a species should cross one or more national boundaries. The BirdLife definition is an ecological one and thus more inclusive in this respect (with some 80 migratory species being single-country endemics and thus not covered by the Convention), although perhaps more stringently applied in terms of the predictability and cyclical nature of movements (with some 130 species listed on the Convention appendices regarded as non-migratory under the BirdLife definition).

For this review, we exclude the 262 extant marine and coastal species that migrate across the world's oceans and along coasts (as, in our view, this group requires a separate, but ideally complementary, study). We also exclude 343 altitudinal migrants and 181 nomadic species that we consider better treated separately from 'true' migratory species. We focus on the 1,593 migratory land- and waterbird species, representing $16 \%$ of the world's birds. Such birds breed in areas with seasonally abundant resources, and move to other areas that offer better survival prospects during the non-breeding season. The distances that these birds travel vary considerably, from relatively short intra-regional movements to intercontinental flights involving considerable risks and energetic costs. Migratory strategies also vary, from short hops with regular refuelling to immense non-stop journeys that are only possible because of extreme fattening and significant changes to body structure and physiology prior to departure. These various types of migration have differing implications for conservation.

For convenience, and to evaluate different conservation needs, we here divide migratory birds into three main groups-landbirds and waterbirds (mutually exclusive), plus soaring birds (which comprise a mixture of land- and waterbird species that migrate primarily by soaringgliding flight)—as explained in the following sections.

\section{Migratory landbirds}

Migratory landbirds (c. 1,230 species in total) include species such as tyrant-flycatchers Tyrannidae (113), buntings and New World sparrows Emberizidae (99), Old World warblers Sylviidae (96), birds of prey Falconiformes (80), chats and Old World flycatchers Muscicapidae (66), pigeons and doves Columbidae (53), swallows and martins Hirundinidae (53), New World warblers Parulidae (52) and cuckoos Cuculidae (50). The smaller species tend to move on a broad front across the landscape on each continent, in some cases encountering significant obstacles to movement, such as deserts, seas or mountain ranges, which they either cross or bypass, depending on their evolutionary adaptations. Optimal terrestrial landscapes for these species on migration are ones that offer suitable and sufficient habitat in which to forage and rest, before and after such long flights and during stopovers. It follows that the availability and maintenance of such habitats in the landscape is a key conservation requirement for these birds. 


\section{Migratory waterbirds}

Many waterbirds are migratory (c. 360 species), including many ducks, geese and swans Anatidae (c. 80), shorebirds Charadriiformes (c. 130), loons Gaviidae, grebes Podicipedidae, flamingos Phoenicopteridae, storks Ciconiidae, ibises, spoonbills Threskiornithidae, bitterns, herons, egrets Ardeidae, pelicans Pelecanidae, rails Rallidae and cranes Gruidae. As with landbirds, waterbirds also either overfly or detour around large inhospitable expanses of land or sea that lack suitable wetlands for resting and refuelling. Where the number of such staging posts is limited, waterbirds can congregate in spectacular fashion, and these sites are crucial to the success of their migratory journeys. Thus the loss of one site can have a potentially devastating impact (see below, and Baker et al. 2004).

\section{Migratory soaring birds}

Some larger broad-winged migratory land- and waterbirds, 'soaring birds', cannot maintain active flapping flight over long distances and rely on columns of rising hot air (thermals) to enable them to migrate by a more passive soar-and-glide method (c. 130 species). These include many birds of prey such as eagles and hawks, but also some waterbirds, including storks, spoonbills and pelicans. Such birds tend to follow routes that provide good opportunities for soaring flight, even if not the most direct. Migratory soaring birds have great difficulty crossing large bodies of water, because in much of the world sufficiently strong thermals can only form over land. The birds must therefore follow routes that avoid long sea-crossings, by using landbridges (often referred to as 'bottlenecks') such as the Isthmus of Panama (in the Americas) and the Bosphorus (Europe) or by taking the shortest possible sea-crossings such as the Straits of Messina and of Gibraltar (Europe-Africa), and the Gulf of Suez and the Bab el-Mandeb (Middle East-Africa). Mountain ranges also cause funnelling of soaring birds (in this case through the lowest available mountain passes), and cranes (though not strictly 'soaring birds', being capable of sustained active flight) are also particularly sensitive to this constraint. It is clearly vital that important routes are not affected or developed in a way that would adversely affect the massive concentrations of soaring birds that use them.

\section{Distribution and flyways}

As outlined above, migratory birds travel from breeding to non-breeding areas, and back again, either on a broad front through the landscape or via clearly defined, and sometimes narrow, routes. The total geographic area used by a population, species or group of species throughout its annual cycle is termed a flyway. Such flyways can be delineated by interpretation of morphological differences between some populations, analysis of genetic differences, ringing/ banding results, stable-isotope ratios in feathers, and satellite-based and geolocation tracking. One of the commonest patterns is for birds to breed in the temperate, boreal or Arctic biomes of the northern hemisphere during the northern summer, and then to spend the non-breeding season in the warmer biomes of the tropics, with fewer species migrating very long distances to reach the temperate zones of the southern hemisphere during the southern summer. Another common pattern is for intra-tropical migrants to follow the productive 'wet season' as it oscillates annually from the Tropic of Cancer to the Tropic of Capricorn and back again. The predominant migratory pattern in the southern hemisphere is for birds to breed in the temperate latitudes of South America, Africa and Australasia, and then to migrate to the tropics and subtropics in the southern winter. However, probably mainly because there is so much less land in the southern than in the northern hemisphere, many fewer species are involved (see further details on migratory patterns in Supplementary materials). Relatively good knowledge (and easier identification of key sites) allows the waterbird and soaring bird flyways to be quite clearly described (see Boere and Stroud 2006 for a detailed history of waterbird flyways; Zalles 
Table 1 . Numbers of migratory species by type and region.

\begin{tabular}{lllll}
\hline Broad regions & Landbirds & Waterbirds & Soaring birds & TOTAL \\
\hline Americas & 617 & 202 & 45 & $\mathbf{8 1 9}$ \\
Europe, Central & 420 & 162 & 67 & $\mathbf{5 8 2}$ \\
Asia, Africa \& & & & & \\
Middle East & & 201 & 73 & $\mathbf{7 2 8}$ \\
Asia-Pacific & 527 & & & \\
\hline
\end{tabular}

\section{Notes}

The sum of the totals by region or type exceeds the total number of migratory species $(1,593)$ because some species occur in more than one region, and soaring birds are not exclusive of landbirds or waterbirds.

and Bildstein 2000 for soaring bird flyways); the routes taken by other landbirds are generally less well understood and consequently remain less distinctly defined.

The numbers of migratory species can be summarised according to region and country (see Table $I$ and Annex $I$ in Supplementary materials; data from BirdLife International 2008b). North and Central America, the Caribbean, Europe, Central Asia, the Middle East and Africa are all important, supporting more than 300 species each. However, the South American and Asian regions stand out, supporting more than $30 \%$ of all migratory land- and waterbird species occurring there (538 and 678 species respectively). The countries with the highest numbers (335-522) of migratory species (with regular native occurrence when breeding, non-breeding or on passage) include: Canada and the USA in North America; Mexico in Central America; Brazil, Bolivia and Argentina in South America; Iran in the Middle East; and China, Asian Russia and India in Asia. While high numbers of migratory species are partly a consequence of country size, knowing the absolute numbers of species by country is useful for targeting conservation efforts where many species will benefit.

\section{Stop-over sites}

During migration, birds need suitable habitat for feeding, resting or moulting. Where suitable habitat areas are widely spaced, most of the population uses the same network of individual sites (this is less the case for broad-front migrating landbirds). Piersma (1987) describes the 'hop, skip and jump' migration strategies of migrant birds, whereby some migrants fly relatively short distances every day/night with 'hops' taking the birds from site to site along the migration route. These birds require closely interspersed habitats. Other species, those that encounter ecological barriers, such as large expanses of sea, are forced to 'skip' or fly without stopping for great distances. In this scenario the habitats at each end of this migration are particularly important. The final group of migrants makes incredible flights that are truly a long-distance 'jump', sometimes from one hemisphere to another. After perhaps more than doubling in weight, these birds depart and fly non-stop, making truly amazing journeys in order to reach their final destination. It is clear that appropriate stop-over sites are critical to the successful migration of most bird species, as well as rich feeding areas in departure and arrival locations.

For Nearctic migrants in North America, Mehlman et al. (2005) reviewed the importance of stop-over sites and provide a useful framework for the categorisation of different types. Although designed for forest-dwelling, nocturnally migrating landbirds relying on stop-over habitats in parts of Canada and the United States, this typology is adaptable to other geographic regions and to other groups of migratory birds. At one end of a continuum are type 1 ('fireescape') stop-over sites. These are infrequently used, but are vital in emergencies. Type I sites are typically adjacent to significant barriers, such as large bodies of water, deserts, or intensively altered landscapes, and are typically small and isolated habitat refugia surrounded by unusable habitat. More central along the continuum are type 2 ('convenience store') stop-over sites. These 
are defined as places where birds can briefly rest (i.e. any stop-over of two days or less) and easily replenish body reserves. Sites of this type function to support birds between short flights to higher-quality sites or when fuel needs are moderate. The ideal type 2 site is structurally heterogeneous, contains fresh water, and provides a variety of food resources. At the other end of the continuum, a type 3 ('full service hotel') stop-over site is an extensive area of habitat appropriate for migratory birds. These are places where all necessary resources (i.e. food, water, shelter) are relatively abundant and available and which serve many individuals of many species. Individual passerines may remain at type 3 sites for one to several days (while in the case of waterfowl and waders, birds may remain at the same site for weeks), because essentially all immediate resource needs are supplied and associated risks are relatively low, allowing them to attain peak physiological condition and continue their migration to their next stop or final destination.

\section{Status of migratory species}

Insights into the global status of migratory species can be gained from BirdLife's categorisation of bird species on the IUCN Red List (BirdLife International 2008b). In 2008, of the 1,593 migrants as defined here, 177 (I1\%) were considered threatened or near-threatened ( 13 'Critically Endangered', 25 'Endangered', 73 'Vulnerable', and 66 'Near Threatened'; see Annex 2 in Supplementary materials). Regionally, there are some differences according to bird species type, notably with the Palearctic-African and Asia-Pacific regions having the highest proportion of threatened waterbirds ( $16 \%$ and $23 \%$ ) and soaring birds ( $24 \%$ and $33 \%$ respectively) (see Table 2).

It is also possible to examine the global trends of waterbirds (irrespective of IUCN Red List category changes) owing to the regular status reviews coordinated by Wetlands International and published in the Waterbird Population Estimates series. According to Delany and Scott (2006), 40\% of populations for which trend data are available at the global level are decreasing, $34 \%$ are stable, and only $17 \%$ are increasing (note, however, that although the majority of waterbirds included in these figures are migratory, separate figures are not available for just the migratory populations). A further 52 populations $(4 \%)$ have already become extinct.

Table 2. Numbers and percentages of threatened and near-threatened migratory species by type and region.

\begin{tabular}{lcccc}
\hline Broad regions & Landbirds & Waterbirds & Soaring birds & TOTAL \\
\hline Americas & $47 / 579^{1}$ & $18 / 202$ & $1 / 45$ & $\mathbf{6 5} / \mathbf{8 1 9}$ \\
Europe, Central & $8 \% \%^{2}$ & $9 \%$ & $2 \%$ & $\mathbf{8 \%}$ \\
Asia, Africa \& & $29 / 365$ & $26 / 162$ & $16 / 67$ & $\mathbf{5 5} / 582$ \\
Middle East & $8 \%$ & $16 \%$ & $\mathbf{2 4} \%$ & $\mathbf{1 0 \%}$ \\
Asia-Pacific & $52 / 477$ & $46 / 201$ & $24 / 73$ & $\mathbf{9 8 / 7 2 8}$ \\
& $11 \%$ & $23 \%$ & $33 \%$ & $\mathbf{1 4 \%}$ \\
\hline
\end{tabular}

\section{Notes}

The sum of the totals by region or type exceeds the total number of migratory species $(1,593)$ because some species occur in more than one region, and soaring birds are not exclusive of landbirds or waterbirds.

${ }^{1}$ Number of threatened and near-threatened migratory species / total number of migratory species occurring in the region.

${ }^{2}$ Percentage of the total number of migratory species occurring in the region that is threatened or nearthreatened. 


\section{Red List Index for migratory species}

By examining the number of species moving between IUCN Red List categories as a result of genuine deterioration or improvement in status, it is possible to calculate Red List Indices (RLI) which illustrate the net change in overall threat status (projected extinction risk) of sets of species (Butchart et al. 2004, 2007; for methodology see Supplementary materials). An RLI for migratory land- and waterbird species (Figure I) shows that, since 1988, 33 species have deteriorated in status while only six species have improved (43 genuine changes overall, see Annex 2 for details of species in Supplementary materials).

Given that migrants depend on different areas to survive, one might expect them to be more threatened overall than non-migrants, since they run the risks of being affected by adverse changes in both breeding and non-breeding areas, and also while on migration (Newton 2008). However, they appear to be less threatened on average than non-migrants (II \% threatened or near-threatened compared to $23 \%$ for non-migrants; Figure 1). This may be because overall migratory land- and waterbird species tend to have larger ranges (and usually higher populations) than non-migratory species, as many breed at high northern hemisphere latitudes and there is a general trend of declining median range area from high northern latitudes to high southern ones (Orme et al. 2006). Thus they are most likely to qualify as threatened on account of population declines (with species declining by at least $30 \%$ over 10 years or three generations qualifying as 'Vulnerable' under IUCN Red List criterion A). Given that population declines are difficult to assess for species with large ranges, it is possible that migratory species may be more threatened with extinction than currently estimated, although we do not have any evidence that such declines are being systematically missed. On the other hand, migratory behaviour may have evolved as a 'coping mechanism' for surviving seasonally unfavourable conditions, and thus may confer some flexibility to respond to regionalised threats.



Figure 1. The Red List Index of species survival for migratory land- and waterbird species and non-migratory species. Notes For migratory species, $n=1,590$ (3 'Data Deficient' species excluded); for other species, $n=8,201$ (63 'Data Deficient' species excluded, 1 species which became extinct after 1988 included). An RLI value of 1.0 equates to all species being categorised as 'Least Concern', and indicates that no species is expected to go extinct in the near future; an RLI value of zero indicates that all species have gone extinct (see Supplementary materials). 


\section{Regional status in the America flyways}

In North America, declines have been reported for landbirds from studies of individual species, geographical areas and migration sites, and from the results of continent-wide monitoring. For example, Robbins et al. (1989) used Breeding Bird Survey (BBS) data to examine the population trends of migrants and resident bird species in eastern North America during 1966-1987. Over the years $1978-1987,44(71 \%)$ of 62 Nearctic-Neotropical migrants showed declines in abundance, compared to similar declines in $15(48 \%)$ of 32 residents and Nearctic-Nearctic migrants. Robbins et al. (1989) concluded there was "...a general decline in NearcticNeotropical migrants throughout eastern North America". Re-analyses of the BBS data confirmed that rates of Nearctic-Neotropical migrant decline were pronounced in eastern North America during the 1980s, exceeding those documented in both central and western regions of the continent (Sauer and Droege 1992, Peterjohn et al. 1995). Recent BBS census results suggest that the Nearctic-Neotropical migrant declines of the 1980 s have continued and spread in their geographical extent. During 1980-2005, 62\% of Nearctic-Neotropical migrants in the eastern BBS region showed negative population trends, while in the western BBS region, an area not previously recognised for its dwindling migrant populations, $65 \%$ were categorised as declining (Sauer et al. 2005). However, population declines are not restricted exclusively to NearcticNeotropical migrants. For example, temperate-zone migrants in the western BBS region have also been subject to widespread recent declines, with $70 \%$ of species documenting negative population trajectories between 1980 and 2005 . Moreover, there have been continent-wide declines in the abundance of grassland-breeding birds since 1980, with $86 \%$ of species exhibiting negative population trend estimates (Sauer et al. 2005).

The status of austral migrants in South America has not been the focus of a region-wide analysis, though Stotz et al. (1996) identified 68 species to be of conservation concern in the short to medium term. At particular risk was a group of species, typified by several species of seedeater Sporophila spp., that rely on grassland habitats in southern South America. These species breed primarily in the grasslands of north-eastern Argentina, southern Paraguay, southern Brazil and Uruguay and winter in the campo grasslands of the cerrado region of central Brazil.

\section{Regional status in African-Eurasian flyways}

A recent continent-wide analysis of the trends of European breeding birds (using data in BirdLife International 2004a) showed that, during 1970-2000, populations of Palearctic-African migrant birds have undergone a pattern of sustained, often severe, decline (Sanderson et al. 2006). The trends of intercontinental migrants were significantly more negative than those of shortdistance migrants or residents, with 48 (40\%) of 119 exhibiting substantial negative population trends. These negative trends appeared to be largely, although not entirely, restricted to species spending the northern winter in dry, open habitats in Africa. Analyses of trends of 30 closely related pairs of species, one a long-distance migrant and the other not, indicated significantly more negative trends in the former, irrespective of breeding habitat.

Delany et al. (2007) reviewed the status of waterbirds covered by the African-Eurasian Waterbird Agreement (AEWA) specifically and considered that, overall, the trend status of waterbirds in the Agreement area worsened between 1999 and 2006. However, this was mainly because of a decrease in the proportion of known populations estimated to be increasing, from $25 \%$ in 1999 to $22 \%$ in 2006 ; the proportion estimated to be decreasing stayed at about the same level, $41-42 \%$.

According to Goriup and Tucker (2007) at least 39 (51\%) of 77 migratory raptor species in Africa and Eurasia are globally threatened or near-threatened or declining. In Europe, a particularly high proportion $(62 \%)$ of raptor species has an unfavourable conservation status (see Table 3). Furthermore, analysis of their population trends indicated that nearly a third are 
Table 3. The status of breeding populations of migratory raptors in Europe, Asia, the Middle East and Africa (adapted from Goriup and Tucker 2007).

\begin{tabular}{|c|c|c|c|c|}
\hline Conservation Status ${ }^{1}$ & Europe $^{2}$ & $\mathrm{Asia}^{3}$ & Middle East & Africa \\
\hline Unfavourable & 18 & 9 & 1 & 4 \\
\hline Unfavourable (uncertain) ${ }^{4}$ & 11 & 5 & 1 & 2 \\
\hline Total unfavourable & 29 & 14 & 2 & 6 \\
\hline Favourable & 8 & 4 & o & o \\
\hline Favourable (uncertain) & 10 & 9 & 4 & 8 \\
\hline Unknown & o & 34 & 11 & 17 \\
\hline $\begin{array}{l}\text { Total no. migratory } \\
\text { raptor spp. }\end{array}$ & 47 & 61 & 17 & 31 \\
\hline
\end{tabular}

${ }^{1}$ Conservation status is defined in accordance with CMS Article $I(c)$ and includes populations that are small and non-marginal, declining more than moderately (i.e. $>_{\mathcal{I}} \%$ per year), depleted following earlier declines, or are highly localised.

${ }^{2}$ Based on Birds in Europe (BirdLife International 2004a).

${ }^{3}$ Excluding countries in the Middle East.

${ }^{4}$ Defined for Europe as species that have a provisional European Threat Status and are not globally threatened.

declining rapidly (i.e. by more than $1 \%$ per annum) and $21 \%$ have suffered large declines averaging over $3 \%$ per annum in the last 1o years. Similarly, from analysis of one major migration route in the region, the Rift Valley/Red Sea Flyway, Tucker (2005) found that 27 $(69 \%)$ of 39 soaring birds assessed had an unfavourable conservation status. Generally, however, there is little accurate knowledge about the status of breeding and wintering raptor populations in Africa-Eurasia.

\section{Regional status in East Asian-Australasian flyways}

The status of migratory birds in this region has not yet been the focus of detailed, continental analysis, as for the Nearctic and Palearctic migrants. However, South-East Asia, which is a major wintering area for migrants from eastern Asia, is affected by extensive deforestation, so declines in Asian landbirds, many of which winter in subtropical and tropical forests, may reasonably be expected. For example, Wells (2007) cites recent historical loss of more than $90 \%$ of the ThaiMalay Peninsula's mangroves and at least $80 \%$ of lowland inland forest. He notes that, at this regional scale, applying guidelines for the regional application of the IUCN Red List criteria, mangrove specialists rarely rate less than 'Near Threatened', and species tied to well-structured forest below $150 \mathrm{~m}$ never rate less than 'Endangered'. In Japan, Amano and Yamaura (2007) used distributional data for breeding birds (from 1978 and 1998-2002) to reveal that species with certain traits (of which long-distance migration was one) have indeed experienced severe range contractions. In addition, Asia is the continent of greatest concern with respect to waterbird trends: $62 \%$ of waterbird populations are now decreasing or have become extinct and only 10\% show an increasing trend (Delany and Scott 2006). A recent review of long-term trends of shorebird populations in eastern Australia (Nebel et al. 2008) reports that migratory populations have plummeted by $79 \%$ over a 24 -year period. A review of questionnaire responses from raptor specialists on the status of migratory raptors in central, southern and eastern Asia (Goriup and Tucker 2007) indicated that $17(33 \%)$ of the 51 migratory raptors considered currently exhibit an unfavourable conservation status, although the status of many species is uncertain.

\section{Key threats}

Analysis of the main threats to migratory land- and waterbird species evaluated as threatened and near-threatened on the 2008 IUCN Red List (BirdLife International 2008b; see Figure 2, also 




Figure 2. Main threats to threatened and near-threatened migratory land- and waterbird species (those evaluated as threatened and near-threatened in BirdLife 2008b). Categories of threat follow Salafsky et al. (2008).

Supplementary materials) shows that the two key pressures, affecting nearly $80 \%$ of these species, come from agricultural activities (resulting in habitat loss/degradation) and biological resource use (also resulting in habitat loss/degradation largely owing to logging or wood harvesting [affecting c. $20 \%$ ]), as well as causing direct mortality from over-harvesting [ $>50 \%$ ] and persecution [c.10\%]). Other important threats, affecting 30-50\%, include pollution, natural system modifications (owing to, e.g., dams and wetland drainage), residential and commercial development, human disturbance and the impact of invasive and non-native species, including emerging diseases.

These threats are common to birds generally, whether considered globally threatened or not. For example, Tucker and Goriup (2005, updated in Goriup and Tucker 2007) found that the main threats to raptors in Africa and Eurasia with an unfavourable conservation status are those causing habitat loss and degradation (Table 4). Other threats include shooting (especially in the Mediterranean basin, for sport and trophies), poisoning, electrocution by powerlines, deliberate persecution and disturbance during the breeding period. Collisions with wind turbines may become a significant problem, and many existing threats are likely to be exacerbated by climate change.

Many of these threats to birds have been highlighted for a long time (see, e.g. Biber and Salathé 1991), but the scale and intensity of pressures on birds have increased as economies and human populations have grown (e.g. BirdLife International 2004b). Some of these threats, including that from climate change, are explored further in the following sections, concentrating especially on threats of particular relevance to migratory birds.

\section{Land-use pressures}

Delany and Scott (2006) cited land-use changes and resulting habitat destruction as the most frequent known cause of population decrease in waterbirds, highlighting concerns in Asia where the "...frantic pace of economic development is clearly having adverse impacts on the environment, including numbers and population trends of waterbirds". This was further emphasised by Stroud et al. (2006), reviewing the conservation status of wading birds on the 
Table 4. Summary of threats to migratory raptors in Africa and Eurasia that have an Unfavourable Conservation Status ${ }^{1}$ (adapted from Goriup and Tucker 2007). Magnitude of impacts: Low $=$ unlikely to cause detectable population impacts in most species; Moderate = likely to cause local population impacts in most species, or population declines in some species; High = likely to cause population declines in most species. Blank $=$ threat currently unknown in region.

\begin{tabular}{|c|c|c|c|c|c|c|}
\hline \multirow[t]{2}{*}{ Threat types } & \multicolumn{2}{|c|}{ No. spp. impacted } & \multicolumn{4}{|c|}{ Magnitude of impacts ${ }^{2}$} \\
\hline & Breeding & Non-breeding & Europe & $\mathrm{Asia}^{3}$ & $\begin{array}{l}\text { Middle } \\
\text { East }\end{array}$ & Africa \\
\hline
\end{tabular}

- Loss to agriculture and agricultural intensification

- Abandonment

- Over-grazing

- Forest loss and management

- Afforestation

- Wetland loss and degradation

- Burning / fire

- Development

\section{Habitat Loss/Degradation}

$\begin{array}{ccllll}28 & 12 & \text { H } & \text { H } & \text { M? } & \text { H } \\ 10 & \text { 1 } & \text { M } & \text { M } & ? & - \\ 5 & 5 & \text { L } & \text { M? } & \text { M? } & \text { H? } \\ 9 & 1 & \text { M } & \text { M } & \text { L } & \text { M } \\ 12 & \text { O } & \text { M } & - & - & - \\ 13 & 4 & \text { M } & \text { H } & \text { H } & \text { M } \\ 6 & 2 & \text { M } & \text { L } & - & \text { M } \\ 6 & \text { O } & \text { M } & \text { M } & \text { M } & -\end{array}$

- Trade (collections, falconry)

- Egg-collection

- Shooting and trapping

Taking of birds (harvesting / hunting)
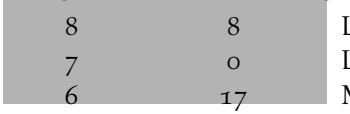

L
L
M
$\mathbf{y}^{4}$

- Collision with man-made structures

- Electrocution on power lines

- Poisoning (e.g. by baits for other species)

- Nest destruction

Accidental mortality ${ }^{4}$

Persecution



M

L

L?

M L

L $\quad-$

$\mathrm{H} \quad \mathrm{L}$

- Land pollution ${ }^{5}$

- Water pollution ${ }^{5}$

- Toxic pesticides

- Disturbance (human)

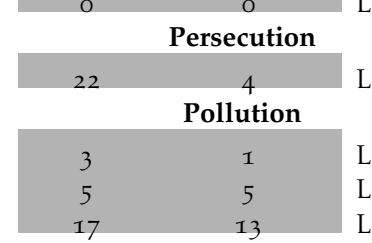

Disturbance

\begin{tabular}{lc|c|ccc}
21 & 2 & $H$ & L & $M$ & $M$ \\
7 & 5 & & & & \\
& Other & & &
\end{tabular}

- Other

L L L

H L L

M $\quad \mathrm{M} \quad \mathrm{L}(\mathrm{H}$ in

parts)

L $\quad-\quad$ L

M M L

L L $\quad-$

M L L

M? M? $\quad$ M?

${ }^{1}$ Conservation status is defined in accordance with CMS Article $I(c)$.

${ }^{2}$ The magnitude of the impact is based on a subjective assessment for the next 1o years, taking into account each threat's average extent, severity and predicted trends across all African-Eurasian migratory raptor species (see Goriup and Tucker 2007, Table 7 for details).

${ }^{3}$ Excluding countries in the Middle East.

${ }^{4}$ Individuals are killed accidentally (but see Pollution where this may also be the case) rather than intentionally (see Hunting, Persecution).

${ }^{5}$ Land/water pollution does not include pesticides, which are coded separately. 
East Asian-Australasian flyways, noting the enormous pressures in the region, which contains over a third of the world's human population as well as some of the world's fastest-growing economies. According to Stroud et al. (2006), consequences of this development include: over $80 \%$ of wetlands in East and South-East Asia classified as threatened, with more than half under serious threat; and in China and South Korea, $37 \%$ and $43 \%$ of inter-tidal wetlands destroyed by land reclamation respectively (with more underway).

As noted above, habitat loss and degradation are widespread threats to migratory raptors in Africa and Eurasia. This is mainly as a result of agricultural expansion and intensification, which are widespread in developing regions and continue in more developed countries. Overgrazing (which reduces prey populations) is also a major problem in many parts of Africa, and probably Asia and the Middle East, although quantified data on actual impacts are lacking. In fact, whilst many apparent pressures were identified, Goriup and Tucker (2007) were unable to attribute population declines in migratory raptors to impacts encountered specifically during migration, as opposed to impacts on the breeding or non-breeding areas.

In Europe, the decline in birds breeding on farmland from about 1970 onwards is well documented and largely attributable to agricultural intensification on that continent (e.g. Pain and Pienkowski 1997, Donald et al. 2001). Sanderson et al. (2006), however, concluded that agricultural impacts on the breeding grounds were unlikely to be the sole cause of declines in Palearctic migrants. Instead, the negative trends they documented appeared to be largely driven by declines in species spending the northern winter in dry, open habitats in Africa. Newton (2004) also noted that declines in Palearctic-African migrants have mainly involved species that spend the northern winter in, or pass through, the semi-arid savannas of tropical Africa, which have suffered from the effects of drought and increasing desertification. In addition to climate change, Newton (2004) highlighted the importance of factors such as overgrazing, burning, woodcutting, drainage of wetlands and pesticide use which reduce the quantity and quality of habitats available to migrant birds during the non-breeding season.

In North America, numerical declines in migrant landbirds have affected many forest species. For Nearctic-Neotropical migrants at least, forest fragmentation in breeding areas has been shown to be important in contributing to the declines of these birds (Robbins et al. 1989, Terborgh 1989, Newton 2008, Ewing et al. 2008). Tropical deforestation in the non-breeding areas of Central America and on the Caribbean islands may also be important, but Ewing et al. (2008) found insufficient evidence to make a general case for migrant bird populations being currently limited by non-breeding habitat quantity and/or quality.

\section{Habitat destruction and degradation at special sites}

Newton (2004) noted that population sizes might be limited by severe competition at restricted stop-over sites, where bird densities are often high and food supplies heavily depleted. To date, the evidence for population regulation through factors at migration sites is limited, but at least one study has demonstrated that it may be very significant. This concerns the Red Knot Calidris canutus rufa subspecies that migrates annually between the Canadian Arctic and Tierra del Fuego. This population has undergone a drastic recent decline, from 100,00o individuals in 1989 to just 17,200 in 2006. Although the causes are not yet fully understood, the decline is mainly attributed to the low availability of Horseshoe Crab Limulus polyphemus eggs, a key food resource for Red Knot, in Delaware Bay, the final staging-post before the non-stop flight to its Arctic breeding grounds. The lack of eggs has been linked to an elevated harvest of adult crabs for bait in the conch and eel fishing industries (e.g. Baker et al. 2004, USFWS 2007).

Another species that has undergone a recent dramatic decline (of up to $70 \%$ since the 1970s) is Spoon-billed Sandpiper Eurynorhynchus pygmeus with just 350-380 pairs estimated to remain in 2005 (Zöckler and Syroechkovski submitted). It breeds on a small strip of coastal Arctic tundra in Chukotka, north-east Russia, and winters along coasts in South and South-East Asia, depending on the rich tidal coasts of the Yellow Sea for refueling. Habitat destruction along this 
flyway, notably recent massive land claim at the important staging area of Saemangeum in South Korea, has been listed as a contributory factor in the decline.

\section{Mortality owing to artificial structures}

Newton (2007) collated information on bird mortality caused by human artefacts, such as powerlines, wind turbines, gas flares and telecommunications masts. Tall buildings and ceilometers (lights used for measuring cloud height) and tall illuminated masts used for radio, television and mobile telephone transmission all kill migrant birds (mainly by collision), especially those flying at night. In North America in the 1970s, an estimated 1.3 million migrants were killed in this way each year (Banks 1979). By 2000, tower numbers had increased roughly fourfold, as had the associated death toll, reaching an estimated 4-5 million birds per year (USFWS 2002). About 350 species have been recorded as casualties, the vast majority being Nearctic-Neotropical migrants that fly at night, including a variety of warbler (Parulidae) species.

Modern wind turbines are known to kill migrants by night or day (reviewed in Newton 2007), but information is only just beginning to emerge on the scale of these losses (which generally seem relatively small, being estimated at a total of 33,00o birds per year in the United States: USFWS 2002). The greatest losses seem to occur at wind farms situated on narrow migration routes (for example, raptors in south-west Spain), or near wetlands, which attract large numbers of gulls and other large birds (de Lucas et al. 2007). An analysis of the impact of wind farms on birds (Langston and Pullan 2004) identified the main potential hazards as disturbance leading to displacement and exclusion, collision mortality, and loss of, or damage to, habitat, but acknowledged that there had been few comprehensive studies, and even fewer published, peerreviewed scientific papers. Langston and Pullan (2004) noted that most studies have quoted low collision mortality rates per turbine, but in many cases these are based only on corpses found, leading to under-recording of the actual number of collisions. Moreover, relatively high collision mortality rates have been recorded at several large, poorly sited wind farms in areas where concentrations of birds are present, especially migrating birds, large raptors or other large soaring species. As turbines continue to be constructed, they could collectively begin to impose a more significant drain on migratory bird populations, whether on land or in shallow coastal areas.

Powerlines also pose a significant collision risk for many larger migrant birds (e.g. swans and geese), especially if sited across flight lines or close to congregatory sites such as wetlands. Furthermore, electrocution on poorly designed medium-voltage lines is a significant cause of mortality in large perching species such as raptors (Bevanger 1998, Haas et al. 2003). For example, Moseikin (2003) reported at least 311 raptor electrocutions over a 10o-km section of 10 $\mathrm{kV}$ power line in Kazakhstan over one year. Of particular concern, in central Mongolia, is the electrocution of Saker Falcon Falco cherrug (an 'Endangered' species), with this factor apparently the primary cause of adult mortality in the region (Gombobaatar et al. 2004).

\section{Unsustainable harvesting}

Many researchers have considered whether mortality from harvesting is compensatory (not causing extra deaths overall) or additive (Newton 1998). For waterbirds at least (reviewed by Kirby et al. 2004), when harvests exceed a critical threshold compensation does not appear possible and populations can be driven into decline (e.g. Lesser White-fronted Goose Anser erythropus). Cases of bird populations responding positively to reduced hunting pressure (e.g. Trumpeter Swan Cygnus buccinator, Canada Goose Branta canadensis) indicate that populations may well be maintained at lower than 'normal' levels by hunting. In Western Europe, waterbird populations have responded positively to the establishment of refuges and stronger legal protection under a wider package of measures governed by the EC Wild Birds Directive. The 
reduction of harvesting that was the result of these measures will have positively contributed to these changes in numbers.

In the Maltese Islands, a location central to important migratory routes in the AfricanEurasian Flyway system, Raine (2007) revealed that at least 75 migratory species, from 35 countries, had been killed there, a high proportion being protected birds of prey (including Redfooted Falcon Falco vespertinus and Lesser Kestrel F. naumanni), and concluded that illegal hunting in Malta alone could have serious negative impacts on the overall conservation status of many migratory species.

For soaring birds that concentrate at bottleneck sites, shooting may result in high mortality, for example when birds are forced to fly low or come to ground because of bad weather (Porter 2005). Although there has been no systematic assessment of numbers of soaring birds killed at bottleneck sites in the Middle East and north-east Africa, Porter (2005) noted that hunting was common in at least four countries and was perceived as the most serious threat at seven $(32 \%)$ of 22 bottleneck sites evaluated.

Harvesting and hunting of birds of prey (including egg collecting, chick collecting for falconry, poisoning, and shooting) remain a significant threat in many areas of the African-Eurasian region, despite being illegal in most places (Tucker and Goriup 2005). Birds have routinely been shot in many countries for sport and trophies, particularly in the Mediterranean region and parts of the Middle East (e.g. Baumgart et al. 1995, 2003, Bijlsma 1990, Giordano et al. 1998, Portelli 1994, van Maanen et al. 2001). There is little up-to-date information on current shooting and trapping levels on migration routes, and recent legislation and better enforcement may have reduced mortality rates; even so, and although population-level impacts are not currently measurable for any migratory raptor species, the numbers taken annually are probably sufficient to have significant impacts on some species, especially already threatened species with lowreproductive rates (Tucker and Goriup 2007).

\section{Human disturbance}

Human activities, including all forms of work or leisure activity taking place in close proximity to birds, may cause disturbance (Woodfield and Langston 2004). Disturbance is also an important indirect consequence of hunting (see Madsen and Fox 1995, Mainguy et al. 2002, Kirby et al. 2004). Overall, such effects are likely to be widespread and, whilst we generally do not know whether there are population-level impacts, local effects may be substantial.

Assessing the significance of disturbance has proved to be complex, with the need to record and consider many interacting variables and take account of many differing species attributes, situations and sensitivities. Large-scale field experiments (see Madsen 1998a, 1998b, Mainguy et al. 2002) have demonstrated potentially important effects of hunting disturbance in depressing the size of waterbird populations. In addition, breeding season research has demonstrated that human disturbance can force incubating birds off nests, separate adults from free-ranging young, lead to increased nest predation, prevent access to preferred feeding areas by adults and/or young, and increase energy costs if birds are forced to move when resting (examples in Kirby et al. 2004). During the non-breeding season, disturbance may frequently cause displacement, either between or within sites, influence feeding and resting behaviour, result in increased daily and seasonal energy expenditure overall, and increase the chance of predation. This may affect the condition and fitness of migratory species.

\section{Disease and parasites}

All species are exposed to disease but anthropogenic factors-including loss and/or degradation of habitat, pollution, over-harvesting, increased interface between wild and domestic/captive/ human populations, intensive management of wildlife and global climate change-can disturb this balance and sometimes cause great mortality. 
Waterbirds in particular are prone to periodic outbreaks of infectious disease at sites where they congregate at any time of year. Such outbreaks have increased as a cause of mortality in wild waterbirds and significantly impact on some populations (e.g. Friend 2006; Kuiken et al. 2006; Rocke 2006a). A notorious source of mass mortality among migrant waterbirds is botulism, caused by a neurotoxin in the bacillus Clostridium botulinum. The occurrence of botulism is largely controlled by environmental factors and is not dependent on waterbird density, and thus this disease has the potential to cause significant population declines in some species, seriously impeding conservation efforts. Year-to-year losses from botulism are highly variable, but they can be substantial: 4-5 million waterfowl deaths were attributed to botulism in the western United States in 1952 (see Newton 2008). In 2002-2003, a botulism outbreak in Taiwan killed more than $5 \%$ ( 73 birds) of the world population of Black-faced Spoonbill Platalea minor (Yu 2003). In 1996, an outbreak at the Salton Sea, California, killed nearly $15 \%$ of the western population of American White Pelicans Pelecanus erythrorhynchos. Rocke (2006b) indicates that, on a world-wide basis, avian botulism is the most significant disease of waterbirds.

Avian influenza viruses are found in a wide range of bird species, especially aquatic ones, including ducks, geese, swans, waders and gulls, which act as a reservoir for the low pathogenic forms of the virus. These viruses live in balance with their natural hosts and do not normally cause population effects. Recently, there has been an emergence of a high pathogenic avian influenza (HPAI) virus $\left(\mathrm{H}_{5} \mathrm{~N}_{1}\right)$ in South-East Asia. Many wild birds die from HPAI $\mathrm{H}_{5} \mathrm{~N}_{1}$ infection, resulting in localised waterbird die-offs, though susceptibility is species specific (e.g. Brown et al. 2006, 2008). Some wild bird species are little affected, but can potentially transmit the virus along migratory routes, although it is unknown to what extent this actually happens. Some spread of the virus appears attributable to migratory bird movements, but the relative significance of different modes of spread is poorly understood at present (e.g. Kilpatrick et al. 2006, Gauthier-Clerc et al. 2007). HPAI $\mathrm{H}_{5} \mathrm{~N}_{1}$ does appear to pose a threat to some migratory waterbird species that congregate at only a few specific sites, as shown by the loss of $10 \%$ of the world population of Bar-headed Goose Anser indicus on Qinghai Lake in China in 2005 (Liu et al. 2005).

\section{Climate change}

Climate change is expected to exacerbate habitat-related pressures on migratory birds (Sanderson et al. 2006, Tucker and Goriup 2007). It may mediate competition between shortand long-distance migrants by allowing short-distance migrants to return earlier to their shared breeding grounds, and possibly by enhancing overwinter survival of birds remaining in Europe, leaving intercontinental migrants at a competitive disadvantage (Sanderson et al. 2006). A predicted increase in the frequency of storms could result in significant losses for landbirds migrating over water (e.g. Butler 200o). Moreover, as the ranges of pathogens and vectors shift, migratory bird populations, already under pressure from other threats, may come into contact with 'new' diseases.

Robinson et al. (2005) demonstrated many changes in bird populations that they attributed to the effects of climate change, including:

- changes in range and timing and direction of migratory routes, beneficial for many temperate species but deleterious for high Arctic and montane species (a high proportion of which are migratory) as the area of suitable habitat is likely to decline markedly;

- changes to the timing of breeding, beneficial if allowing more breeding attempts, deleterious if leading to asynchrony with food supplies (although many migratory species have changed the timing of their migrations in response to changed conditions, others have not);

- changes in survival, beneficial for temperate migrants by increasing winter temperatures near the limits of the breeding range (and decreasing mass mortality events), deleterious for trans-equatorial migrants if precipitation declines as predicted; 
- changes in productivity, beneficial among many species over the last few decades, at least in the UK, but potentially deleterious to some ground-nesting species which may be adversely impacted by increased precipitation.

Newton (2008) concluded that many bird species have changed some aspect of their migratory behaviour during the last century or more, in response to changed conditions, with (I) earlier arrival in spring, (2) earlier or later departure in autumn, (3) shortening or lengthening of migration routes, (4) directional changes, and (5) reduced or enhanced 'migratoriness', reflected in changes in ratios of resident to migratory individuals in breeding areas, and in the occurrence of wintering birds in areas previously lacking them. Almost all these changes were associated with changes in food availability or with climatic conditions likely to have affected food supplies, such as milder winters. Most cases of increasing migratoriness involved species that have extended their breeding ranges into higher latitudes where overwintering is impossible or risky.

Huntley et al. (2007) projected how the ranges of 430 European breeding birds (including many migratory land- and waterbird species) may shift by the end of this century in response to climate change. Three alternative future climate scenarios, differing in the magnitude of the range changes that result, were applied to models of species' current distribution and in all cases produced the same general results. Species' breeding ranges will generally shift north-eastwards and by large distances (several hundred kilometres for many species), and on average will be $20 \%$ smaller than they are now, with limited overlap (c. $40 \%$ ) with their present breeding distributions. For at least some high arctic breeders, climate change modelling shows an almost complete loss of habitat (Zöckler and Lysenko 2000).

Impacts of climate change on long-distance migrants are likely to be complex (Sanderson et al. 2006). The rate, direction and variability of climate change differ considerably between regions (IPCC 2001). These effects could change the timing of resource availability, affecting the timing of migration or movement between staging areas (Schaub et al. 2005) and leading to asynchrony between resource availability and resource requirements. These likely changes on migrant populations may vary widely between regions and species (Bairlein and Húppop 2004) and urgently need further investigation (Sillett et al. 2000).

\section{Improving the knowledge base}

Good science, necessary for good conservation, is especially challenging for migratory species that spend different periods of their annual cycles in different parts of the world. Generally we need more information on:

- global population sizes for many species in order to detect current or future declines and act to address them;

- what is causing declines, drawing out geographic or ecological commonalities between declining species to help us to identify and address the threats at the root of these declines;

- locations/migration routes used by birds at different stages of their annual cycle so that we can address threats at these locations and achieve effective protection;

- ecological requirements at different stages of the annual cycle, in order to implement effective habitat management for them at key sites or in the wider landscape;

- how migratory bird species will respond in the face of global climate change (a good understanding of the ecology, population size and current distribution of migratory species will help us to predict how climate change may impact these species and to address their needs proactively);

- what kind of network of habitat patches/sites (including the size, proximity and number of patches) would be needed to support healthy populations of different migratory species at all stages of their annual cycle, and how we can maximise the resilience of such networks in the face of global climate change. 
Obtaining such information requires substantial research, careful analysis and agreement on targets relevant to range and abundance for each migratory species. It also requires comparisons of current provisions in relation to 'ideal states' and an assessment of the feasibility of creating more effective habitat/site networks.

Critically, we need to identify which migratory species are declining in which regions and the principal reasons for their declines. This is particularly important in Asia (including the Indian subcontinent) and South America where information is generally poor or non-existent. It is vital to continue the monitoring already underway (for example, the International Waterbird Census, Common Bird Monitoring in Europe and Breeding Bird Surveys in North America) in order to detect changes, including future declines, and the success (or not) of conservation measures. Moreover, it is critical to extend the coverage of these types of monitoring schemes both in geographic terms-extending to other sites and regions not currently covered-as well as in temporal terms-extending to different seasons (covering both spring and autumn migrations). These research and monitoring activities come at a price, and governments with a shared responsibility for migratory species must be persuaded to fund work essential to underpin appropriate conservation action for migratory species.

\section{Conservation approaches}

The conservation of migratory birds requires a multitude of approaches, for specific species, for site networks, and for habitats in the wider environment. Migratory birds are popular with the public, and can provide an entry point for raising awareness about some of the bigger environmental issues facing the world.

\section{Protecting species}

For migratory species, legal protection can be an important starting point, backed up by awareness and enforcement. Good examples include Dalmatian Pelican Pelecanus crispus and White Pelican $P$. onocrotalus in Europe, which are recovering in response to good implementation of legal protection measures (Kirby et al. 2004). Illegal hunting and trapping have been successfully confronted in some regions such as the northern Mediterranean and parts of eastern Asia (e.g. Taiwan). Many migratory species have benefited from international agreements (see below), and species action plans, management plans and programmes have had a positive impact for some (e.g. Black-faced Spoonbill Platalea minor in east Asia, Kirtland's Warbler Dendroica kirtlandii in North America, and Puna Flamingo Phoenicoparrus jamesi in the Andes). However, as noted by Davidson and Stroud (2006), species-focused arguments may not influence decision-makers when there are apparent trade-offs between the maintenance of natural ecosystems and sustainable development. More persuasive are likely to be arguments that stress the importance of maintaining and enhancing habitat biodiversity and natural processes which, in turn maintain the ecosystem services upon which both birds and humans depend.

\section{Safeguarding a network of important sites}

Effective management of critical sites, and coordinated planning and management along migration flyways as a whole, are vital to many migratory birds. BirdLife International's Important Bird Areas (IBA) programme provides a platform for planning, prioritising, advocating and taking action for sites, as well as monitoring the effectiveness of this action. IBAs are identified on the basis of the presence of birds that are globally threatened and nearthreatened (covering 177 migratory species), spatio-temporally concentrated ( 384 congregatory migratory species), geographically restricted (59 migratory species with small breeding ranges), 
Table 5. Numbers of IBAs identified for significant numbers of migratory species by type and region. Data are taken from BirdLife's World Bird Database; additional sites may have been identified but are not yet included in the database. Although inventories are progressing, few IBAs for migratory species have been identified in Antarctica, Australasia and Oceania. The sum of the totals by type by region exceeds the total number of IBAs by region as IBAs can be identified for both land- and waterbirds, and soaring birds are not exclusive of landbirds or waterbirds. All totals refer to IBAs of global importance. Some IBA criteria are applied at the level of species-assemblage rather than individual species or otherwise cover a mixture of species and have therefore not been analysed here.

\begin{tabular}{|c|c|c|c|c|}
\hline Regions & Landbirds & Waterbirds & Soaring birds & TOTAL \\
\hline \multicolumn{5}{|c|}{ Inventories complete } \\
\hline Africa & 200 & 376 & 189 & 501 \\
\hline Asia & 455 & 835 & 619 & 1,032 \\
\hline Caribbean & 27 & 16 & $\mathrm{o}$ & 43 \\
\hline Europe & 639 & 1143 & 653 & 1,536 \\
\hline Middle East & 96 & 94 & 62 & 157 \\
\hline \multicolumn{5}{|c|}{ Inventories in progress } \\
\hline Central America & 61 & 24 & 5 & 82 \\
\hline Central Asia & 181 & 193 & 222 & 295 \\
\hline North America & 8 & 176 & 34 & 181 \\
\hline South America & 117 & 87 & 3 & 196 \\
\hline
\end{tabular}

and biome-restricted (374 migratory species, based on breeding ranges only) (details in Supplementary materials). Thus IBAs are being identified proactively for $>700$ migratory species (c. $45 \%$ of the total). To date, over 4,000 sites have been identified worldwide on the basis of migratory 'trigger' species (Table 5).

The adequacy of these sites as a network of breeding, non-breeding and passage areas is regularly reviewed by BirdLife International. An international collaboration between Wetlands International and BirdLife International in close coordination with other partners, the 'Wings Over Wetlands' (WOW) Project, is a recent example of this work in the area covered by the African-Eurasian Waterbird Agreement (AEWA), aiming "to improve the conservation of African-Eurasian migratory waterbirds through implementing measures to conserve the critical network of sites that these birds require to complete their annual cycle" including stop-over sites during migration and in wintering grounds. Central to the project's rationale is the creation of a comprehensive flyway-scale 'critical sites network tool' for display and management of the most up-to-date information about the species and sites, using IBAs as the starting point. This involves reviewing the current IBA network species by species (c. 300 in total) and flyway by flyway, taking account of spatial, seasonal and numerical representation (Figure 3).

In the African-Eurasian Waterbird Agreement (AEWA) area, hosting over 2,250 IBAs known to support at least one species of migratory waterbird, nearly $40 \%$ are currently lacking either statutory national protection or international recognition as Ramsar Sites, natural World Heritage Sites or Biosphere Reserves (unpublished data held in BirdLife's World Bird Database). Few IBA bottleneck sites for migrating raptors in Africa and Eurasia have adequate protection (Goriup and Tucker 2007). In the tropical Andes, where IBAs for migratory birds have been recently identified, $43(37 \%)$ are not protected (BirdLife World Bird Database data). However, formal protection of IBAs may not always be necessary or appropriate, provided that such sites are safeguarded through land-use planning, policy and legislation (including EIA legislation, and the safeguard policies of lending institutions and donor agencies).

Effective management of key stopover and bottleneck sites needs to address factors that cause direct mortality, such as over-harvesting, and reduce food supplies, such as habitat destruction or degradation, and pollution. Any unnecessary disturbance (e.g. interference, hunting or 


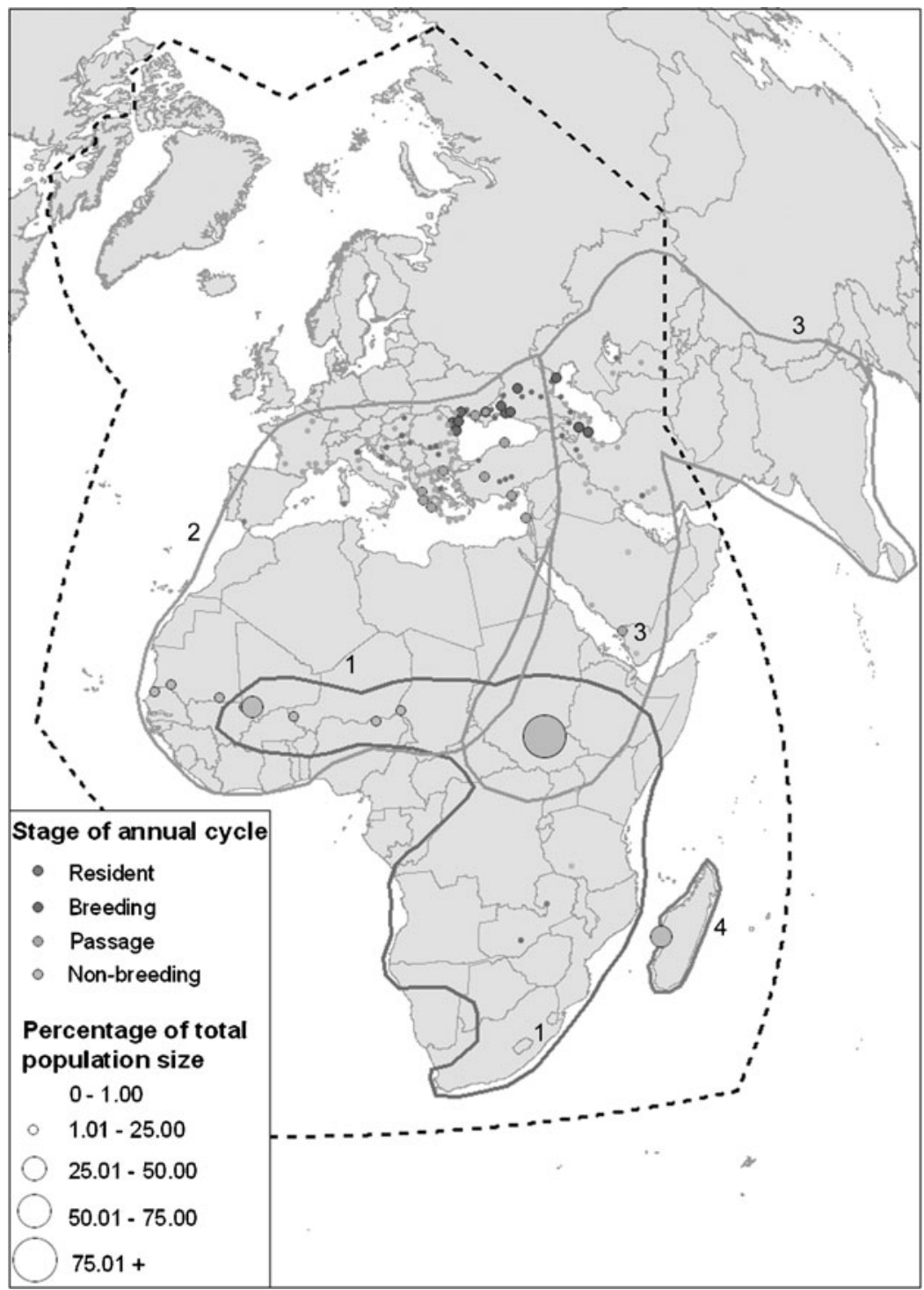

Figure 3. Map showing the four populations of Glossy Ibis Plegadis falcinellus which occur within the AEWA area, and the percentage of each population recorded at IBAs during different stages of the annual cycle. Outline polygons (from Wetlands International) represent population delineations for the subspecies P. f. falcinellus as follows: $1=$ Sub-Saharan Africa; 2 = Eastern and Southern Europe; 3 = South-west Asia; 4 = Madagascar. Black dashed outline shows the extent of the African-Eurasian Waterbird Agreement (AEWA) area. The mean number of individuals recorded in any IBA (from BirdLife's World Bird Database) was converted to a percentage of the total size of the relevant population, as published in Waterbird Population Estimates (Delany and Scott 2006). This was calculated separately for breeding and non-breeding (including passage) stages of the annual cycle. This map (and others like it) is being used to identify gaps in the site (IBA) network and, with additional data, will be used to identify a 'critical site network' for each population of some 300 species through the WOW project (http://www.wingsoverwetlands.org). 
persecution) that causes birds to expend energy in flight or increased vigilance should be avoided, and wind-power, telecommunications and power transmission structures not permitted.

\section{Conserving habitats}

Many migratory species (some 55\%) are widely dispersed in their distributions, especially passerines, and most species that congregate do so only in certain phases of their life cycle. Stopping and reversing declines in migratory species requires addressing the human-induced changes to migratory bird habitats in the broader landscape, in addition to species and site-based work. Habitat transformation-such as agricultural intensification in Europe, conversion of natural rangelands to soy plantations in South America, desertification in the Sahel, tropical deforestation in South-East Asia and Central and South America, and forest fragmentation in North America, all of which are implicated in migratory bird declines-can only be addressed through changes in economic policy and land-use planning. With climate change increasingly also implicated in migratory bird declines, and likely to have profound impacts in the future, the magnitude of the challenge only grows.

\section{International collaboration}

The effectiveness of conservation of migratory birds in one part of their range may be reduced if they are being killed, and their habitats destroyed, elsewhere. International collaboration is thus a key element in any strategy for their conservation. Various relevant policy mechanisms exist, but the key global treaty is the Convention on Migratory Species (CMS, or the Bonn Convention). Parties to CMS (108 states) must prohibit the taking of species on Appendix I ('endangered' species, including many globally threatened migrant birds) and assume responsibility for the species' habitats and the obstacles to migration (including buildings, powerlines and wind turbines). To benefit species on Appendix II, parties must seek agreements, ten of which for birds are currently in operation or under development, ranging from singlespecies treaties (e.g. Aquatic Warbler Acrocephalus paludicola, Siberian Crane Grus leucogeranus) to those covering huge geographical areas and large numbers of species (e.g. the African-Eurasian Waterbird Agreement). Recently concluded Agreements have included those on South American grassland passerines and on Andean flamingos.

An analysis of existing agreements that could help to conserve migratory raptors in Africa and Eurasia (Goriup and Tucker 2005) revealed that a wide range of interlocking (if not partially overlapping) legislation already exists which, in principle, covers all possible threats. However, these arrangements are inadequate owing to the widely recognised drawbacks of much international conservation law, including lack of resources, lack of focus, absence of key range states, difficulties with enforcement, poor cross-compliance and coordination. The clear lack of a unifying international action plan enabling concerted efforts for conserving migratory birds of prey in Africa and Eurasia is now recognised by CMS, and an MoU and action plan are currently being developed (www.cms.int/species/raptors/index.htm).

Another global treaty that exerts key influence on the conservation of migratory birds is the Convention on Wetlands (Ramsar Convention), which designates sites as a means of establishing linked networks of protected areas. Other mechanisms exist at the regional level. In Europe, the Convention on the Conservation of European Wildlife (Bern Convention) has played a key role over many years, and the European Union's Birds Directive is a noteworthy instrument for the conservation of all bird species. In North America, there are several mechanisms, including the Western Hemisphere Migratory Species Initiative, the North American Bird Conservation Initiative, North American Waterfowl Management Plan, Waterbird Conservation for the Americas and the Western Hemisphere Shorebird Reserve Network. While in Asia-Pacific, there is the Asia-Pacific Migratory Waterbird Strategy (which has evolved to become the East Asian-Australasian Flyway Partnership). The Central Asian Flyway has seen developments that 
have lead to the adoption of an action plan for this flyway and a formal agreement is in development. For landbirds, several recent initiatives include 'Partners in Flight' (for passerines and raptors in the Americas) and the UN Global Environment Facility 'Soaring Birds' project (for raptors, storks and other soaring species in Europe, the Middle East and Africa). Adequate funding and effective implementation of these regional and global agreements is essential to safeguard the future of the world's migratory birds.

\section{Some recommendations}

It is beyond the scope of this review to set out in any detail an overall action plan for the conservation of migratory birds. As this paper has progressed we have, however, felt compelled to identify some key actions, on a meaningful scale, that should be taken, and where actions need not be held back because of incomplete data and a lack of consensus.

We have taken the bold, selective, and arguably controversial step of identifying a dozen actions that we feel could be taken now to help reverse the fortunes of the world's migratory birds. There are of course many other important steps that need to be taken, varying in scale, but we hope that highlighting the following will focus minds and empower decision-makers. These 12 actions will not only benefit migratory birds, but will be significant for wider biodiversity, environmental sustainability and reduce the impacts of climate change. It is clear that people will also benefit over the longer term too. All of these are do-able if there is the will, and if we are to come anywhere near to meeting the UN's target of significantly reducing the rate of loss of biodiversity by 2010 .

1. Halt conversion of intertidal wetlands in East Asia, especially in the Yellow Sea.

2. Protect remaining lowland forest in South-East Asia from conversion to plantation agriculture.

3. Reform the Common Agricultural Policy of the European Union, to promote diverse, environmentally sustainable farming that supports biodiversity and rural livelihoods.

4. Ensure full implementation of and adherence to species protection and hunting regulations, especially in the Mediterranean basin.

5. Support efforts to reduce and reverse desertification in the African Sahel, using approaches that protect and restore native vegetation and conserve natural flood regimes.

6. Protect remaining lowland and montane forests in Central America and the tropical Andes.

7. Protect key grasslands in South America and maintain traditional, extensive grassland ranching practices.

8. Protect key sites (Important Bird Areas) for migratory bird species along their flyways, and support the development of flyway-scale site networks (as being developed by the Asia-Pacific Flyway Partnership and Western Hemisphere Shorebird Reserve Network).

9. Ensure best practice, and exercise extreme caution, in the location and construction of man-made structures in sensitive areas for migratory birds, especially wind turbines and power transmission and telecommunication cables.

10. Improve coordination between existing migratory species initiatives throughout the Americas and within the framework of the Western Hemisphere Migratory Species Initiative, augmenting their implementation on the ground.

11. Ensure full implementation of measures under the auspices of the UN Convention on Migratory Species (CMS) including the African-Eurasian Waterbird (AEWA) Agreement, and support the agreement of a Memorandum of Understanding on the Conservation of Migratory Birds of Prey in Africa and Eurasia.

12. Strengthen support and provide funding for monitoring migratory bird populations so that declines can be detected early and appropriate action implemented rapidly.

These are not a comprehensive or global set of recommendations, rather a selection of actions that would achieve maximum impact and might, by example, help to address similar problems, as well as opportunities, that exist in other areas that we do not highlight. 


\section{Acknowledgements}

We thank Leon Bennun, Rob Clay, Nigel Collar and Lincoln Fishpool of BirdLife International for helping to shape this paper and for commenting on earlier drafts; also Jez Bird, James Gilroy, Simon Mahood, Lucy Malpas, Andy Symes and Joe Taylor for their work on evaluating the status of the world's birds and checking various attributes in BirdLife's World Bird Database, including migratory status. We acknowledge the generous input of thousands of contributors and collaborating organisations who provide BirdLife with information on the status, distribution and threats to the world's birds and the conservation actions needed and underway for them. We thank Debbie Pain and Steven Ewing of the Royal Society for the Protection of Birds for their valuable input, including giving us access to an unpublished review of declines of Nearctic-Neotropical migrants, work that has been funded by Natural England under the Action for Birds in England Programme. We thank David Stroud of the UK Joint Nature Conservation Committee and Ward Hagemeijer of Wetlands International for their very useful comments and suggestions. The review of the status of raptors in Africa and Eurasia was funded by the UK Department for Environment, Food and Rural Affairs as a contribution to the development of a proposed regional conservation instrument for migratory birds of prey under the Convention on Migratory Species. We are grateful to the staff of JUST ECOLOGYfor discussions and support. The compilation of this review has been partly funded by Vogelbescherming Nederlands (BirdLife in the Netherlands) as a contribution towards the development of a global BirdLife flyways initiative.

\section{References}

Amano, T. and Yamaura, Y. (2007) Ecological and life-history traits related to range contractions among breeding birds in Japan. Biol. Conserv. 37: 271-282.

Bairlein, F. and Húppop, O. (2004) Migratory fuelling and global climate change. Adv. Ecol. Res. 35: 33-47.

Baker, A. J., Gonzalez, P. M., Piersma, T., Niles, L. J., deLima Serraro do Nascimento, I., Atkinson, P. W., Clark, N. A., Minton, C. D. T., Peck, M. K. and Aarts, G. (2004) Rapid population decline in Red Knots: fitness consequences of decreased refuelling rates and late arrival in Delaware Bay. Proc. R. Soc. Lond. B. 271: 875-882.

Banks, R. C. (1979) Human-related mortality of birds in the United States. U. S. Fish Wildl. Serv. Spec. Sci. Report 215: 1-16.

Baumgart, W., Kasparek, M. and Stephan, B. $(1995,2003)$ [Birds of Syria]. Max Kasparek/ Verlag. English edition by the Ornithological Society of the Middle East, Berlin.

Bevanger, K. (1998) Biological and conservation aspects of bird mortality caused by electricity power lines: a review. Biol. Conserv. 86: 67-76.
Biber, J.-P. and Salathé, T. (1991) Threats to migratory birds. Pp. $17-35$ in T. Salathé, ed. Conserving migratory birds. Cambridge, UK: International Council for Bird Preservation (Technical Publication no. 12).

Bijlsma, R. G. (1990) Bottleneck areas for migratory birds in the Mediterranean region: an assessment of the problems and recommendations for action. Cambridge, UK: International Council for Bird Preservation.

BirdLife International (2004a) Birds in Europe: population estimates, trends and conservation status. Cambridge, UK: BirdLife International.

BirdLife International (2004b) State of the world's birds 2004: indicators for our changing world. Cambridge, UK: BirdLife International.

BirdLife International (2008a) The BirdLife Checklist of the birds of the world with conservation status and taxonomic sources. Version 1. Available at www.birdlife. org/datazone/species/downloads/BirdLife_ Checklist_Version_1.xls. 
BirdLife International (2008b) Threatened birds of the world 2008. CD-ROM. Cambridge, UK: BirdLife International.

Boere, G. C. and Stroud, D. A. (2006) The flyway concept: what it is and what it isn't. Pp. 40-47 in G. C. Boere, C. A. Galbraith and D. A. Stroud, eds. Waterbirds around the world. Edinburgh, UK: The Stationery Office.

Brown, J. D., Stallknecht, D. E., Beck, J. R., Suarez, D. L. and Swayne, D. E. (2006) Susceptibility of North American ducks and gulls to $\mathrm{H}_{5} \mathrm{~N}_{1}$ Highly Pathogenic Avian Influenza viruses. Emerging Infectious Diseases 12: 1663-1670.

Brown, J. D., Stallknecht, D. E. and Swayne, D. E. (2008) Experimental infection of swans and geese with Highly Pathogenic Avian Influenza virus $\left(\mathrm{H}_{5} \mathrm{~N}_{1}\right)$ of Asian lineage. Emerging Infectious Diseases 14: 136-142.

Butchart, S. H. M., Stattersfield, A. J., Bennun, L. A., Shutes, S. M., Akçakaya, H. R., Baillie, J. E. M., Stuart, S. N., Hilton-Taylor, C. and Mace, G. M. (2004) Measuring global trends in the status of biodiversity: Red List Indices for birds. Public Lib. Sci. Biol. 2: 2294-2304.

Butchart, S. H. M., Akçakaya, H. R., Chanson, J., Baillie, J. E. M., Collen, B., Quader, S., Turner, W. R., Amin, R., Stuart, S. N., Hilton-Taylor, C. and Mace, G. M. (2007) Improvements to the Red List Index. Public Lib. Sci. One 2((1)): e140.

Butler, R. W. (2000) Stormy seas for some North American songbirds: are declines related to severe storms during migration? Auk 117: 518-522.

Davidson, N. C. and Stroud, D. A. (2006) African-Western Eurasian Flyways: current knowledge, population status and future challenges. Pp. 63-73 in G. C. Boere, C. A. Galbraith and D. A. Stroud, eds. Waterbirds around the world. Edinburgh, UK: The Stationery Office.

Delany, S. and Scott, D. (2006) Waterbird population estimates. Fourth Edition. Wageningen: Wetlands International.

Delany, S., Scott, D. A., Helmink, T. and Martakis, G. (2007) Report on the conservation status of migratory waterbirds in the Agreement area. Third edition. Bonn, Germany: AEWA (Technical Series no.13).
Donald, P. F., Green, R. E. and Heath, M. F. (200I) Agricultural intensification and the collapse of Europe's farmland bird populations. Proc. R. Soc. Lond. Ser. B Biol. Sci. 268: 25-29.

Ewing, S. R., Pain, D., Smith, K. W. and Grice, P. V. (2008) A review of population declines amongst Afro-Palearctic migratory birds, and lessons to be learned from the study of the population declines of Neotropical migrants. Sandy, UK: Royal Society for the Protection of Birds (unpublished internal report).

Friend, M. (2006) Evolving changes in diseases of waterbirds. Pp. 412-417 in G. C. Boere, C. A. Galbraith and D. A. Stroud, eds. Waterbirds around the world. Edinburgh, UK: The Stationery Office.

Gauthier-Clerc, M., Lebarbenchon, C. and Thomas, F. (2007) Recent expansion of highly pathogenic avian influenza $\mathrm{H}_{5} \mathrm{~N}_{1}$ : a critical review. Ibis 149: 202-214.

Giordano, A., Ricciardi, D., Candiano, G., Celesti, S. and Irrera, A. (1998) Antipoaching on the Straits of Messina: results after 15 years of activities. Pp. 623-630 in B.-U. Meyburg, R. D. Chancellor and J. J. Ferrero, eds. Holarctic birds of prey. Berlin: ADENEX-World Working Group on Birds of Prey and Owls.

Gombobaatar, S., Sumiya, D., Shagdarsuren, O., Potapov, E. and Fox, N. (2004) Saker Falcon (Falco cherrug milvipes Jerdon) mortality in Central Mongolia and population threats. Mongolian J. Biol. Sci. 2: 13-21.

Goriup, P. and Tucker, G. (2005) Assessment of the merits of an instrument under the Convention on Migratory Species covering migratory raptors in the African-Eurasian region. Bristol. UK: DEFRA.

Goriup, P. and Tucker, G. (2007) Assessment of the merits of a CMS instrument covering migratory raptors in Africa and Eurasia. Bristol, UK: DEFRA.

Haas, D., Nipkow, M., Fiedler, G., Schneider, R., Haas, W. and Schürenberg, B. (2003) Protecting birds from powerlines: a practical guide on the risks to birds from electricity transmission facilities and how to minimise any such adverse effects. Strasbourg: Council of Europe. 
Huntley, B., Green, R. E., Collingham, Y. C. and Willis, G. (2007) A climatic atlas of European breeding birds. Barcelona: Durham University, RSPB and Lynx Edicions.

IPCC (2001) Climate change: the scientific basis. See http://www.grida.no/climate/ ipcc_tar/wgI/index.htm.

Kirby, J., Davidson, N., Giles, N., Owen, M. and Spray, C. (2004) Waterbirds and wetland recreation handbook: a review of issues and management practice. Slimbridge, UK: Wildfowl and Wetlands Trust.

Kilpatrick, M., Chmura, A. A., Gibbons, D. W., Fleischer, R. C., Marra, P. P. and Daszak, P. (2006) Predicting the global spread of $\mathrm{H}_{5} \mathrm{~N}_{1}$ avian influenza. Proc. Natl. Ac. Sci. USA. 103: 19368-19373.

Kuiken, T., Fouchier, R. A. M., Rimmelzwaan, G. F. and Osterhaus, A. D. M. E. (2006) Emerging viral diseases in waterbirds Pp. 418-421 in G. C. Boere, C. A. Galbraith and D. A. Stroud, eds. Waterbirds around the world. Edinburgh, UK: The Stationery Office.

Langston, R. H. W. and Pullan, J. D. (2004) Effects of wind farms on birds. Strasbourg: Council of Europe Publishing (Nature and Environment no. 139).

Liu, J., Xiao, H., Lei, F., Zhu, Q., Qin, K., Zhang, X., Zhang, X., Zhao, D., Wang, G., Feng, Y., Ma, J., Liu, W., Wang, J. and Gao, F. (2005) Highly pathogenic $\mathrm{H}_{5} \mathrm{~N}_{1}$ influenza virus infection in migratory birds. Science Online. Available from http:// www.sciencemag.org/cgi/content/abstract/ 309/5738/1206.

de Lucas, M., Janss, G. F. E. and Ferrer, M. (2007) Birds and wind farms. Madrid: Quercus.

van Maanen, E., Goradze, I., Gavashelishvili, A. and Goradze, R. (2001) Trapping and hunting of migratory raptors in western Georgia. Bird Conserv. Internatn. 11: 77-92.

Madsen, J. (1998a) Experimental refuges for migratory waterfowl in Danish wetlands. I. Baseline assessment of the disturbance effects of recreational activities. J. Appl. Ecol. 35: 386-397.
Madsen, J. (1998b) Experimental refuges for migratory waterfowl in Danish wetlands. II. Tests of hunting disturbance effects. J. Appl. Ecol. 35: 398-417.

Madsen, J. (1995) Impacts of disturbance on migratory waterfowl. Ibis 137: S67-74.

Madsen, J. and Fox, A. D. (1995) Impacts of hunting disturbance on waterbirds: a review. Wildl. Biol. 1: 193-203.

Mainguy, J., Bêty, J., Gauthier, G. and Giroux, G. F. (2002) Are body condition and reproductive effort of laying Greater Snow geese affected by the spring hunt? Condor 104: 156-161.

Mehlman, D. W., Mabey, S. E., Ewert, D. N., Duncan, C., Abel, B., Cimprich, D., Sutter, R. and Woodfrey, M. (2005) Conserving stop-over sites for forest-dwelling migratory landbirds. Auk 122: 1-11.

Moseikin, V. (2003) The operation and construction of fatal powerlines in Russia and Kazakhstan. Sixth world conference on birds of prey and owls, Budapest, Hungary (poster).

Nebel, S., Porter, J. L. and Kingsford, R. T. (2008) Long-term trends of shorebird populations in eastern Australia and impacts of freshwater extraction. Biol. Conserv. 141: 971-980.

Newton, I. (1998) Population limitation in birds. London: Academic Press.

Newton, I. (2004) Population limitation in migrants. Ibis 146: 197-226.

Newton, I. (2006) Can conditions experienced during migration limit the population levels of birds? J. Orn. 147: 146-166.

Newton, I. (2007) Weather-related massmortality events in migrants. Ibis 149: $453-467$.

Newton, I. (2008) The ecology of bird migration. London: Academic Press.

Orme, C. D. L., Davies, R. G., Olson, V. A., Thomas, G. H., Ding, T.-S., Rasmussen, P. C., Ridgeley, R. S., Stattersfield, A. J., Bennett, P. M., Owens, I. P. F., Blackburn, T. M. and Gaston, K. J. (2006) Global patterns of geographic range size in birds. Public Lib. Sci. Biol. 4(7): e2o8.

Pain, D. J. and Pienkowski, M. W. (1997) Farming and birds in Europe: the Common Agricultural Policy and its implications for bird conservation. London: Academic Press. 
Peterjohn, B. G., Sauer, J. R. and Robbins, C. S. (1995) Population trends from the North American Breeding Bird Survey. Pp. 3-39 in T. E. Martin and D. M. Finch, eds. Ecology and management of Neotropical migratory birds: a synthesis and review of critical issues. Oxford: Oxford University Press.

Piersma, T. (1987) Hop, skip, jump? Constraints on migration of arctic waders by feeding, fattening, and flight speed. Limosa 60: 185-194.

Portelli, P. (1994) Large-scale shooting of raptors in the Maltese Islands. Pp. 194-194 in B.-U. Meyburg and R. D. Chancellor, eds. Raptor conservation today. Mountfield, UK: Pica Press.

Porter, R. F. (2005) Soaring bird migration in the Middle East and North East Africa: the bottleneck sites. Cambridge, UK: BirdLife International.

Raine, A. F. (2007) The international impact of hunting and trapping in the Maltese Islands. BirdLife Malta (internal report).

Robbins, C. S., Sauer, J. R., Greenberg, R. S. and Droege, S. (1989) Population declines in North American birds that migrate to the Neotropics. Proc. Natl. Acad. Sci. USA. 86: $7658-7662$.

Robinson, R. A., Learmouth, J. A., Hutson, A. M., MacLeod, C. D., Sparks, T. H., Leech, D. I., Pierce, G. J., Rehfische, M. M. and Crick, H. Q. P. (2005) Climate change and migratory species. Thetford, UK: British Trust for Ornithology.

Rocke, T. (2006a) Disease emergence and impacts in migratory waterbirds. Workshop introduction. Pp. 410-411 in G. C. Boere, C. A. Galbraith and D. A. Stroud, eds. Waterbirds around the world. Edinburgh, UK: The Stationery Office.

Rocke, T. E. (2006b) The global importance of avian botulism. Pp. $422-426$ in G. C. Boere, C. A. Galbraith and D. A. Stroud, eds. Waterbirds around the world. Edinburgh, UK: The Stationery Office.

Salafsky, N., Salzer, D., Stattersfield, A. J., Hilton-Taylor, C., Neugarten, R., Butchart, S. H. M., Collen, B., Cox, N., Master, L. L., O'Connor, S. and Wilkie, D. (2008) A standard lexicon for biodiversity conservation: unified classifications of threats and actions. Conserv. Biol. DOI: 10.1111/ j.1523-1739.2008.00937.x.

Sanderson, F. J., Donald, P. F., Pain, D. J., Burfield, I. J. and van Bommel, F. P. J. (2006) Long-term population declines in Afro-Palearctic migrant birds. Biol. Conserv. 131: 93-105.

Sauer, J. R. and Droege, S. (1992) Geographic patterns in population trends of Neotropical migrants in North America. Pp. $26-42$ in J. M. Hagan and D. W. Johnston, eds. Ecology and conservation of Neotropical migrant landbirds. Washington, DC: Smithsonian Institution Press.

Sauer, J. R., Hines, J. E. and Fallon, J. (2005) The North American Breeding Bird Survey, results and analysis 1966-2005. Laurel, MD: USGS Patuxent Wildlife Research Centre.

Schaub, M., Kania, W. and Koppen, U. (2005) Variation of primary production during winter induces synchrony in survival rates in migratory white storks Ciconia ciconia. J. Anim. Ecol. 74: 656-666.

Sillett, T. S., Holmes, R. T. and Sherry, T. W. (2000) Impacts of a global climate cycle on population dynamics of a migratory songbird. Science 288: 2040-2042.

Stotz, D. F., Fitzpatrick, J. W., Parker, T. A. and Moskovits, D. K. (1996) Neotropical birds: ecology and conservation. Chicago: University of Chicago Press.

Stroud, D. A., Baker, A., Blanco, D. E., Davidson, N. C., Delany, S., Ganter, B., Gill, R., González, P., Haanstra, L., Morrison, R. I. G., Piersma, T., Scott, D. A., Thorup, O., West, R., Wilson, J. and Zöckler, C. (on behalf of the International Wader Study Group) (2006) The conservation and population status of the world's waders at the turn of the millennium. Pp. 643-648 in G. C. Boere, C. A. Galbraith and D. A. Stroud, eds. Waterbirds around the world. Edinburgh, UK: The Stationery Office.

Terborgh, J. (1989) Where have all the birds gone? Princeton: Princeton University Press.

Tucker, G. (2005) Conservation of birds in the eastern sector of the African-Eurasia Flyway System. Migratory soaring birds: 
review of status, threats and priority conservation actions. Huntingdon, UK: Ecological Solutions (report to BirdLife International).

Tucker, G. and Goriup, P. (2005) Assessment of the merits of an instrument under the Convention on Migratory Species covering migratory raptors in the African-Eurasian region: status report. Bristol, UK: DEFRA.

USFWS (2002) Migratory bird mortality. Arlington, Virginia: US Fish and Wildlife Service (Avian mortality fact sheet: http:// birds.FWS.gov/mortality-fact-sheet.pdf).

USFWS (2007) Status of the Red Knot (Calidris canutus rufa) in the western hemisphere. Pleasantville, New Jersey: USFWS.

Wells, D. R. (2007) The birds of the ThaiMalay Peninsula, 2: passerines. London: Christopher Helm.
Woodfield, E. and Langston, R. (2004) Literature review on the impact on bird populations of disturbance due to human access on foot. Sandy, UK: Royal Society for the Protection of Birds (Research Report No. 9).

$\mathrm{Yu}, \mathrm{Y} . \mathrm{T}$. (2003) International Black-faced Spoonbill census: 24-26 January 2003. Hong Kong: Hong Kong Birdwatching Society.

Zalles, J. I. and Bildstein, K. L. (2000) Raptor watch: a global directory of raptor migration sites. Cambridge, UK: Birdlife International and Hawk Mountain Sanctuary.

Zöckler, C. and Lysenko, I. (200o) Waterbirds on the edge. Cambridge, UK: UNEP-World Conservation Monitoring Centre (WCMC Biodiversity Series no. II).

Zöckler, C. and Syroechkovski, E. E. (submitted) Spoon-billed Sandpiper-Critically Endangered globally? [Bird Conserv. Internatn.]

\section{JEFF S. KIRBY*}

JUST ECOLOGY Environmental Consultancy, Woodend House, Woodend, Wotton-underEdge, Gloucestershire, GL12 8AA, U.K.

ALISON J. STATTERSFIELD*, STUART H. M. BUTCHART, MICHAEL I. EVANS, RICHARD F. A. GRIMMETT, VICTORIA JONES

BirdLife International, Wellbrook Court, Girton Road Cambridge, CB3 oNA, U.K.

\section{JOHN O'SULLIVAN}

Royal Society for the Protection of Birds, The Lodge, Potton Road Sandy, Bedfordshire, SG19 $2 D L, U . K$.

\section{GRAHAM TUCKER ${ }^{1}$}

Ecological Solutions Environmental Consultancy, 5 Rosenthal Terrace, Hemingford Grey, Huntingdon, PE28 9BL, U.K.

\section{IAN NEWTON}

Centre for Ecology and Hydrology, Abbots Ripton, Huntingdon, Cambridgeshire, PE2 8 2LS, U.K.

*Authors for correspondence; emails: jeff.kirby@justecology.co.uk; alison.stattersfield@birdlife.org

${ }^{1}$ Present address: Institute for European Environmental Policy, 28 Queen Anne's Gate, London, SWIH $9 A B$, U.K. 